\title{
Turnaround Management through Internal Corporate Venturing: A Case Study of a Seafood Company
}

\author{
Dr. Shilpa Varma ${ }^{1}$, Dr. Rashmi Gopinathan ${ }^{2}$ \\ ${ }^{1,2}$ (Department of Business Management, Padmashree Dr. D.Y. Patil University, India)
}

\begin{abstract}
New business creation is influenced by the five industry and competitive forces proposed by Michael Porter i.e. bargaining power of customers, bargaining power of suppliers, threat of new entrants, threat of substitutes and intensity of competitive rivalry. There is a need for fostering innovation in the light of current competitive realities. Hence the key to success for any organization in the present competitive and dynamic environment is the need to adopt an entrepreneurial strategy by inducing intrapreneurial culture through internal corporate venturing and innovation. Growth of any organization is possible by effectively identifying and exploring opportunities that are market driven.

This paper attempts to highlight as to how any innovation- be it product, process, material or any other type- can be converted into a sustainable competitive advantage to build a firm standing in the arena of business. In order to conduct the research the researchers have adopted a Case Study approach. In this particular study it was observed that the turnaround of the company was based on the innovative mindset of the intrapreneurs. This is done by studying and analyzing the innovation and success of Gadre Marine Export, Mirkarwada, Ratnagiri - Maharashtra.
\end{abstract}

Keywords - Imitation crab stick, Internal Corporate Venturing, Intrapreneurship, Seafood industry, Surimi, Surimi Analogues.

\section{Introduction}

In a world of ever increasing global economy, the idea of corporate entrepreneurship has become a topic that leaders and managers must not only be aware of conceptually but also understand in order to be able to strategize and position for organizational viability. As a growing competitive advantage for organizations, succeeding in corporate entrepreneurship is a necessity in today's market place. In order to succeed, the organization must set a vision that encourages growth, rewards risk taking and leverage innovation by adapting to the very changing global economy.

The key success to any organization in the present competitive and dynamic environment is the need to adopt an entrepreneurial strategy - seeking competitive advantage through continuous innovation by effectively identifying and exploiting opportunities in order to sustain and grow.

\subsection{Intrapreneurial base in an Organization}

The notion of Intrapreneurship is typically associated with new business creation, new product development and offerings by individuals. With the onset of intensifying global competition there is an increasing need for business organizations to become more intrapreneurial to not only survive but to thrive and prosper. Hence corporate entrepreneurship has become an important paradigm in today's business environment. Corporate Entrepreneurship is a much broader concept encompassing innovation, creativity, change and regeneration within the corporate climate or entire organization. Intrapreneurship base in an organization is a concept by which corporate employees at any level of the company - identify and construct a unique business model that offers significant growth opportunities for their company.

\subsection{Internal Corporate Venturing (ICV) for Sustainability}

Out of the various models of successful corporate entrepreneurship, the most widely accepted one is the Burgelman's Process model of ICV (Fig. 1)

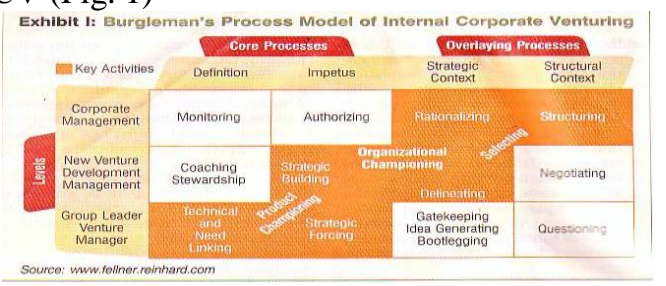

Source: Corporate Entrepreneurship, Effective Executive, The ICFAI University Press, April 2007.

Fig.1: Burgelman's Process model of Internal Corporate Venturing 
As shown in the model, while going for internal corporate venturing, the key activities of the top management include rationalizing and structuring the plan of the new venture. The key activities of middle management or the new venture development management team are strategy building and delineating for the business activities. At the functional level, the group leader or the venture manager has to establish a link between technical requirements and need of the customer and strategically forcing the idea for adoption. There is also an overlap between the top and the middle management in terms of selecting the business plan or people and between middle management and lower management where both of them can act as a product champion.

Burgelman was of the view that the motor of corporate entrepreneurship resides in the autonomous strategic initiatives of individuals at the operational levels in the organization. Therefore, organizations can build a competitive advantage by nurturing the people at the operational level.

\subsection{Sustainability and Innovation}

An Organization can utilize innovations in all phases of its life. However most of the innovations take place when the organizations want to increase the competitiveness in the marketplace. Such innovations are generally of two types- Product Innovation and Process Innovation- both these innovations in the long run result in being "Customer Centric" and thus result in an increasing profit (Gopal, 2007). Implementing the innovation and leveraging the same essentially calls for two broad strategies:

1. The entrepreneur himself takes the risk and steers the organization in that direction with the support of employees.

2. The entrepreneur in consultation with the functional line managers invites a product, process or structural innovation leading to successful business plan and calculated risk.

Strategically after a product has been established in the market place innovations occur when the entrepreneur desires to increase his sales which he achieves through product innovation. This strategically helps in an increase in the market penetration.

With the objective of understanding all these aspects a study was conducted with special reference to the seafood industry.

\section{Rationale of the Research}

The seafood industry in India is primarily an export based industry but also an industry which gives least preference to the area of innovation. A majority of companies are driven by the owners and their mindset for quick profits rather than emphasis on growth through innovation. Hence there is practically no evidence of the concept of ICV being applied. This study is an effort to explore the application of the ICV model in the seafood industry in India and its success or otherwise.

\section{Objective of the Research}

It has been seen that the seafood industry has great potential for economic contribution by innovation of product or process. But no adequate study has been undertaken till now to understand the importance of innovation in product or process in the seafood industry.

The objective of the study was

1. To understand the strategic benefits of Internal Corporate Venturing and innovation.

2. To study the key strategy of the management of Gadre Marine Export for rejuvenation.

3. To highlight the role of intrapreneurial innovation in successful Internal Corporate Venturing w.r.t. Gadre Marine Export.

4. To present the findings of the case study to encourage Indian seafood exporters to leverage innovations for successful intrapreneurial skill sets.

\section{Research Methodology}

An in-depth desk research through secondary data was conducted to understand the various aspects that are involved in the success of corporate entrepreneurship through innovation. Secondary data was also used to acquire an overview of the Indian seafood industry. Several reference books, MPEDA (Marine Products Export Development Authority of India) Journal, FAO Yearbook of fisheries Statistics, project reports of Surimi and Surimi Analouges (by Gadre Marine Exports) were referred to. In addition several newspaper articles as well as websites were searched.

Field research comprised of detailed discussions by the authors with knowledgeable persons in the seafood Industry. A questionnaire was used for the discussion but this had to be discarded as exploratory research had to be undertaken.

Later a pointer method had to be adopted to get a better perspective of the industry and its drivers. The main pointers used were:

* Factors which drive the seafood industry 
Turnaround Management through Internal Corporate Venturing: A Case Study of a Seafood Company

* Problems faced by seafood exporters with special focus on Gadre Marine Exports

* Innovations used by the seafood exporters

* Strategic Leveraging of innovation

A total of 50 knowledgeable persons were contacted. These comprised of:

15 persons from MPEDA (Marine Products Export Development Authority of India)

5 seafood exporters (Allana, FourStar, Chirag, CastleRock, Naik Seafood Exporters)

25 fisheries technologists from Gadre Marine Exports

10 persons who are importers of seafood products from Gadre Marine Exports

\subsection{Steady Growing World demand for Seafood}

\section{Status of Seafood Exporterss in India}

Year after year, since the end of World War II, human beings all over the world have increased their consumption of seafood. The production of seafood has grown from 19 million tones in 1950 to 39 million tones in 1961 and to 130 million tones in 2001. It represents a continuous increase at a yearly rate of 3.84 percent in average.

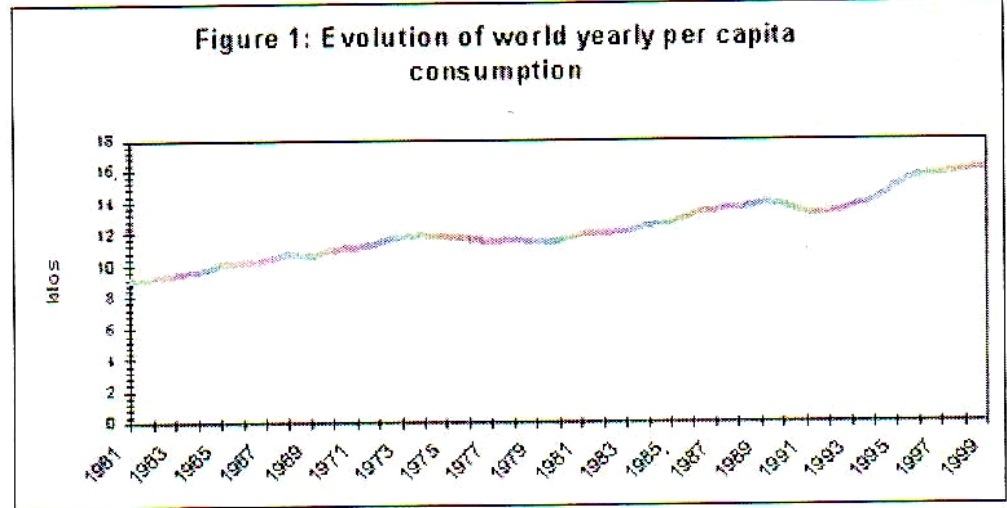

Source: FAO year book of Fishery Statistics, 2000-2001

India is the third largest fish-producing nation in the world, exporting to 73 countries. It has the potential to grow further in view of the growing demand in trading blocks such as the European Union, United States, Canada and Middle East.

There has been huge transformation in the Indian seafood industry over the last few years many of which have not been highlighted or marketed in the international arena. In 1997 the EU banned Indian seafood, citing lack of hygienic and phytosanitary measures in the industry, this was a landmark as thereon India has come a very long way.

The challenge was on and India spearheaded quality control and HACCP was put into place. Today we have excellent facilities, competitive labour and our infrastructure is catching up fast.

Buffeted by the US anti dumping duty, Indian shrimp export is in a major revamp mode. Most of the top and middle level companies are going in for value added products to also create a niche in the global market and control cost effectiveness.

Export diring 2011-12 compored to 2010-12

\begin{tabular}{|l|r|r|r|}
\hline \multicolumn{1}{|c|}{ Export details } & April-March 2011-12 & April-March 2010-11 & \multicolumn{1}{|c|}{ Growth \% } \\
\hline Quantity Tones & 856737 & 813091 & 5.24 \\
\hline Value Rs.crore & 16477 & 12901 & 27.72 \\
\hline US\$ Million & 3484 & 2856 & 21.95 \\
\hline
\end{tabular}

Source: www.seai.in/files/.../export\%20performance\%202011-12.pdf

Table 1: Overall export of Marine products

\subsection{Main Drivers for the Seafood Industry}


Turnaround Management through Internal Corporate Venturing: A Case Study of a Seafood Company

As per the discussions held with the various respondents and an analysis of the information collected by the authors, the following drivers (Strategic/Critical Factors) for the seafood industry were highlighted:

* The quantum of the 'catch'

* Quality as per EU standards

* Marketing and Promotion

* Technology

* Customer Relationship Management

\section{Gadre Marine Exporters: Innovators of Value added Product - "Surimi and Surimi Analog Products"}

Gadre Marine Processing Unit, Mirkarwada, Ratnagiri, was started in 1978 under the proprietorship of Shri Deepak P. Gadre. Initially the unit was processing prawns to export the same to Japan and various countries. The same was done from 1978 to 1993 but it did not prove to be economically successful and financially viable as was conceived originally.

The unit had to face acute financial crisis and to recover it had no other alternative but to search for alternative methods in the same line of verticals. During this decline phase the entrepreneur along with his technical team looked for innovative methods to rejuvenate the existing business. The entrepreneur along with his team directed their attention to use materials which were available at lower cost and started exporting frozen fish namely Ribbon fish and Dhoma which were hitherto considered to be waste in India to S.Korea, Hongkong and Chin.

The curiosity of this export process turned the entire organization to intrapreneurship which further lead to bring in the product and process innovation of "Surimi" -fish paste. In 1992-93 the entrepreneur visited South Korea to have a close look at the process and equipment required for manufacturing Surimi. In 1994 the first India Surimi production unit was set and GME dominated the market as Surimi manufacturers. There was a monopoly by them as suppliers from Indian market globally till 2000 after which there were followers for the innovation like HLL.

Surimi was produced basically by using fish varieties which were not normally eaten in India and which were thrown back into the sea as thrash. The innovation further continued where other marine exporters were thinking of investing in Surimi plant GME further geared up to meet fresh challenges for value addition by manufacturing Imitation crab - sticks from Surimi which had great market in USA and Europe. Constant up gradation and innovation has helped GME to obtain the status of 100\% EOU with export house status from government. It also has the certification of HACCP \& EU. Exports have been growing at a faster rate than the production. Table I gives the year wise turnover of the Unit and the Combined Annual Growth Rate.

\begin{tabular}{|r|c|r|r|}
\hline \multicolumn{1}{l|}{$\begin{array}{l}\text { Sr. } \\
\text { No. }\end{array}$} & Financial year & \multicolumn{1}{|c|}{$\begin{array}{c}\text { Production } \\
\text { Quantity in MT. }\end{array}$} & \multicolumn{2}{l|}{$\begin{array}{l}\text { Export Turnover F.O.B. } \\
\text { Rs.in Lacs. }\end{array}$} \\
\hline 1 & $1993-1994$ & 91.32 & 21.05 \\
\hline 2 & $1994-1995$ & 2782.61 & 938.46 \\
\hline 3 & $1995-1996$ & 3890.00 & 2015.77 \\
\hline 4 & $1996-1997$ & 5349.38 & 2221.81 \\
\hline 5 & $1997-1998$ & 4647.54 & 1833.04 \\
\hline 6 & $1998-1999$ & 3663.54 & 3526.38 \\
\hline 7 & $1999-2000$ & 5826.74 & 5325.54 \\
\hline 8 & $2000-2001$ & 8691.04 & 5966.01 \\
\hline 9 & $2001-2002$ & 10248.16 & 9077.45 \\
\hline 10 & $2002-2003$ & 12489.35 & 6590.59 \\
\hline 11 & $2003-2004$ & 11576.70 & 8531.37 \\
\hline 12 & $2004-2005$ & 13463.73 & 7694.05 \\
\hline 13 & $2005-2006$ & 13031.90 & 8137.22 \\
\hline 14 & $2006-2007$ & 13673.26 & \\
\hline & CAGR & $47 \%$ & \\
\hline
\end{tabular}

Source: Industry Sources

Table 2: The yearwise turnover of the Unit

\section{Analysis and Findings}

A detailed analysis of the strategies used by Gadre Marine Exports helps in revealing the following three Phases of Innovation in the Company.

\subsection{Innovation: Phase I}


- A careful analysis of all the situational factors by the company officials lead to the realization that Ribbon fish and Dhoma which were considered as waste fish in India and thrown back into sea had a vast potential in the Global market. This was never tapped by any Indian Seafood exporter earlier.

- These fishes were bought at very low price as they did not have any market in India.

- They were sold at cost benefit price to S.Korea,Hongkong, China and other countries.

\subsection{Innovation: Phase II}

Success in the export of Ribbion fish and Dhoma by the entire production unit lead to the path way of innovative product and process. This led to the innovative idea of using the minced meat of thrash fish likeDhoma, ribbon fish, lizard fish, Rani, etc. to prepare a delicacy product known as "Surimi”"(a Japanese term for purified fish i.e. skinless, bonless, fatless) is manufactured from fish and used for making various Surimi Products.

- The entire unit was involved in study of the new product, process, equipment and training required for the venture.

- 1994: the first surimi plant was set up in India

- Gadre Marine Exports became the first Indian Exporters in the global market.

- The product "Surimi" product was exported to S.Korea,Japan,Australia,Taiwan, European countries and USA market

- The company applied for and achieved the Status of 100\% EOU,Certification of HACCP \&EU

- Gadre Marine Exporters had the Monopoly as suppliers for Surimi from Indian market till 2000.

\subsection{Innovation: Phase III}

Further innovation was Creating Surimi analogues. Surimi Analog Products are manufactured in various flavours and varieties from Surimi and other eatables and consumed mainly as salad.

- "Imitation crab sticks"is one of the most popular products and hence the highest revenue generator for the company.

- GME became the first Indian entrant in the global market for exporting Surimi Analogs in 2001.

- When competitors were working on Surimi, Gadre Marine Exports worked on the analogues.

\section{Learnings}

A detailed analysis of the three Phases of innovations and the discussions with the respondents indicated the following strategic factors for bringing about continuous innovations leading to competitive advantage and enhancement in the core competencies of the business:

1. Identifying and serving customers in a way that is distinct from competitors.

2. Ability to exploit business opportunity when it arises.

3. Right attitude of entrepreneur and the organisational employees.

4. Loyalty of Key Employees who see benefit in long term commitment of the business.

5. Lower cost of capital: Reinvestment of profits back into the business.

6. Keeping strategies well guarded.

7. Flexibility to leverage innovation.

8. Customer service which are closely tied.

Through innovation as a strategic tool there were positive outcomes at several stages and GME created successful corporate environment and growth in business:

- Total turnaround in the business where the ROI increased every year.

- Cost effective operation, as very low cost fish which were considered as thrash were utilized for creating a new product.

- Delivering the product in the individual brand name in the global market which was a very rare achievement in the seafood industry could be made possible because of very few suppliers for the surimi product in the global market.

- Setting up the first Indian Surimi plant and creating a business model for the other seafood exporters.

- Creating a niche for themselves not only in the South Asian market but also in the European and American market which is very difficult.

- As they were initiators for surimi and surimi analogues in India, they held monopoly in the export market.

- GME created new roles in the organization.

$>$ Technical innovators

$>$ Business Innovators

$>$ Product Champions. 
- Generated huge employment opportunities in the peeling shed.

- Created value addition for fish suppliers making a strong bonding, creating a path to convert thrash fish to productive raw material.

- The organisation became a business model for MPEDA (Marine Product Export Development Authority) Government of India and other Seafood exporters.

\section{The Future Issues}

- To manage expectations in the right way and keep the motivation towards ongoing innovation alive.

- To set of specific metrics to analyze and evaluate new businesses in their development and to decide when to abort a new initiative.

- Set quantitative and qualitative standards which are agreed by all in the organization to have hassle free operations.

\section{Conclusion}

From the detailed study and analysis of concepts and theories of corporate entrepreneurship and innovation relating it to the case study which has been undertaken for study it can be concluded that the primary aim of internal corporate venturing is the revival and rejuvenation of organization resulting in growth and the prime source of it as explored in the above discussion is innovation. The innovation be it product, process or any other type of innovation can be converted into a sustainable competitive advantage to make a firm standing in the arena of business. Organization leveraging innovation, avoids one major organizational conflict associated with entrepreneurship i.e. the distinction between the entrepreneur supported business and corporate entrepreneurship. Entrepreneurs can develop conducive environment of trust and by leveraging innovation they can create collective wealth for the organization as well as contribute to the growth of the country.

\section{References}

[1] Clark, Jon 1995 Learning Through Corporate Ventures. Managing Innovation, pp. 279-309.

[2] Pramodita Sharma, James. J.Chrisman, Toward a reconciliation of the definitional issues in the field of Corporate Entrepreneurship, Entrepreneurship theory and practice, 1999.

[3] Covin, Jeffrey. G. and Selvin, Dennis P. 1991. A Conceptual model of Entrepreneurship.

[4] FAO year book of fishery Statistics (2000-2001).

[5] MPEDA Journal.

[6] Project Report for Surimi and Surimi Analogues (Gadre Marine Exports).

[7] Corporate Entrepreneurship, Effective Executive, The ICFAI University Press, April 2007.

[8] C.J. Punnathara, Shrimp Exporters Turn innovative, The Hindu Business Line,

[9] http://www.thehindu.com, Major Brand building drive for marine exports planned 17/06/2006.

[10] Dr. R. Gopal, 'Innovation- The Key Strategic Weapon to Increase Competitiveness- A Model to Measure the Impact of Innovation on the Value of Business,' Proceedings of the $10^{\text {th }}$ Strategic Management Convention, IIT Mumbai, 2007.

\section{ANNEXURE I}

\section{PROFILE OF GADRE MARINE EXPORT PVT.LTD.}

1] Name \& Address of the Company :- Gadre Marine Export Pvt.Ltd., Plot No.FP-1, Mirjole Block,

2]Date of incorporation

3] Date of establishment

4] Chairman

5] Directors

i) Managing Director

ii) Director

6] Project

$$
\text { :- 12.05.1994 }
$$

M.I.D.C., Ratnagiri - 415639Maharashtra.

:- 21.03.2004

:- Mr.Deepak P. Gadre

:- Mr.Arjun D.Gadre

:- Mrs. Meena D. Gadre

:- $100 \%$ E.O.U. The project is in two phases:-

a] Production of Surimi Analog Products

$$
\&
$$

b] Production of Surimi (Fish Paste).

7] Present Status of the project

8] Industry

a] Name of the Products To be manufactured and their use.

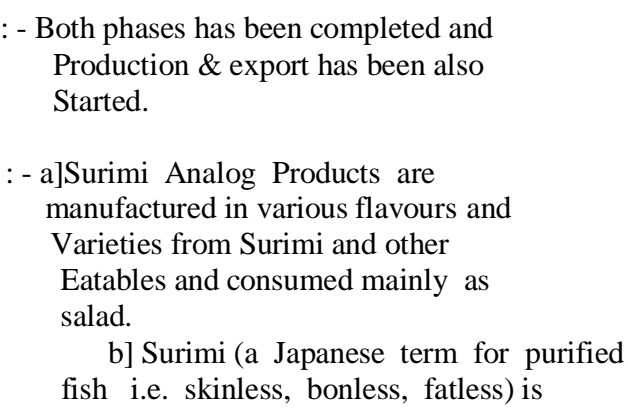




\begin{tabular}{|c|c|}
\hline & $\begin{array}{l}\text { manufactured from fish and used for } \\
\text { making various Surimi Products. }\end{array}$ \\
\hline b] Project Plant Capacity (Annual) & $\begin{array}{cc}\text { :- a]Surimi } & \text { :- } 71175 \text { M.Tons } \\
& \text { b] Surimi Analog Products:-15768 M.Tons }\end{array}$ \\
\hline c] Details of By-products if any & $\begin{array}{l}\text { :- 1] Fish Skin, Bones, Fish Oil, } \\
\text { 2] Gelatin Product, Di Calcium }\end{array}$ \\
\hline $\begin{array}{l}\text { d] Sector } \\
\text { e] Nature of Business }\end{array}$ & $\begin{array}{l}\text { Phosphate. } \\
\text { :- Private Sector } \\
\text { Closely held Private Limited Co. } \\
\text { :- Manufacture and export of Surimi } \\
\text { And Surimi Analog Products. }\end{array}$ \\
\hline f] Nature of Industry & :- Fisheries. \\
\hline $\begin{array}{l}\text { 9] A] Investment made in the } \\
\text { Project }\end{array}$ & :- Rs. 72.50 Crores appx. \\
\hline $\begin{array}{l}\text { B] Present turnover of the Unit } \\
\text { C] Projected turnover for the } \\
\text { F.Y. 2007-08 }\end{array}$ & :- Rs. 60 to 65 Crores appx. \\
\hline $\begin{array}{l}\text { 10] Name of the countries where } \\
\text { the product exported. }\end{array}$ & $\begin{array}{l}\text { :- 1] For Surimi - Japan, S.Korea, } \\
\text { Singapore, Hongkong, Malaysia, } \\
\text { Russia, Spain. } \\
\text { 2] For Crabstick - European countries, } \\
\text { America, S.Korea. }\end{array}$ \\
\hline
\end{tabular}

\section{ANNEXURE II \\ LIST OF AWARDS RECEIVED BY THE FIRM}

Mr. Gadre has been awarded various prizes in India for excellent performance of export and product quality. The main awards received by the firm are as follows:-

a) CEU Awards, Confederation of Export Units award for excellence in exports during the year 1994-95, 1995-96 , 1996-97,

b) Awarded by Income Tax Office Kolhapur, under their scheme 'SAMMAN' for the Assessment Year 1998-99,

c) National Productivity Council of India Award for Productivity performance during the year 1996-97,

d) National Productivity Council of India - First Award for Productivity enhancement for the year 1999-2000,

e) Awarded by The United Western Bank Ltd. in 2000-2001,

f) National Productivity Council of India - Second Award for Productivity enhancement for the year 2000-01,

g) National Productivity Council of India - Second Award for Productivity enhancement for the year 2001-02,

h) National Productivity Council of India - Second Award for Productivity enhancement for the year 2002-03,

i) Export House - Certificate of Recognition for two star export house,

j) The Marine Products Export Development Authority (MPEDA) - Export Performance Award for export to New Markets during - 2005-06. 